\title{
Immigration Background and Differences in School-to- work Trajectories of Early School Leavers'
}

\section{Olav Nygård ${ }^{2}$}

Research Assistant, Remeso, Linköping University, Sweden

\begin{abstract}
This article focuses on the school-to-work trajectories of early school leavers in Sweden. I use sequence analysis of population-level registry data covering the first 10 years after compulsory school for 6404 early school leavers to identify four clusters of school-to-work trajectories: an exclusion trajectory characterized by not being in employment, education, or training; an education trajectory characterized by second-chance education and an increasing share of tertiary education; a precarity trajectory; and a career trajectory. Having an immigrant background or being a woman was associated with a lower likelihood of being in the career trajectory than having a non-immigrant background or being a man. Differences in the likelihood of being in the education trajectory between persons with immigrant and non-immigrant background could however be fully explained by parents' education, if education level was measured relative to their country of origin. This highlights the importance of pre-migration factors for post-migration outcomes.
\end{abstract}

\section{KEYWORDS}

Early school leavers / immigrant background / income / life course / school-to-work transition

\section{Introduction}

ver the last quarter century, the important transitional stage between education and work has changed. From being a relatively compressed and uniform period, it has extended in time and become increasingly de-standardized (Brzinsky-Fay \& Solga 2016). A key feature of the extended transitional phase is the increasing enrolment in further education. However, far from everyone follows this path (Côté 2014). Instead, a large proportion of young people leave school without a diploma from secondary education. In Sweden, 30\% of the 1995 birth cohort had not attained a diploma from upper secondary education within five years of finishing compulsory school (Statistics Sweden 2017b).

Young adults who do not attain a diploma from upper secondary education within five years of finishing compulsory education are often referred to as early school leavers (Cederberg \& Hartsmar 2013; Skolinspektionen 2014; Behtoui et al. 2018), even though the term is debated (Vogt et al. 2020). Early school leavers tend to come from poor families, have parents with low education, belong to disadvantaged minority groups (such as the Roma people), have migrant backgrounds, or have learning difficulties such as dyslexia, autism, or ADHD (Elffers 2012; Cederberg \& Hartsmar 2013).

\footnotetext{
${ }^{1}$ You can find this text and its DOI at https://tidsskrift.dk/njwls/index.

${ }^{2}$ Corresponding author: olav.nygard@liu.se.
} 
Because of the importance of education for labor-market outcomes, early school leavers often struggle in the labor market. The factors associated with early school leaving are often also associated with disadvantages in the labor market, presenting a further obstacle to school-to-work transitions (Van Praag \& Clycq 2019).

Still, many early school leavers find ways to succeed (Schoon \& Duckworth 2010). Often, second-chance education plays an important role. Once outside the standard education system, many early school leavers in Sweden enter the adult education system (Bäckman et al. 2011). The school-to-work trajectories of early school leavers consequently lead both in and out of education. Despite this, previous research has mainly focused on the factors leading students to leave school early, leaving the transitions that follow understudied (Van Praag \& Clycq 2019).

In this article, I use data on Swedish early school leavers from the 1984 and 1985 birth cohorts to address this research gap. The aim is to explore the school-to-work trajectories of early school leavers, and how migration background, family resources, and gender relate to them. Specifically, I answer two questions:

(1) Based on variations in education and earnings, what types of school-to-work trajectories exist for Swedish early school leavers?

(2) To what extent is migration background, family resources, and gender associated with different school-to-work trajectory among Swedish early school leavers?

\section{Early School Leaving in Sweden}

The Swedish education system is comprehensive. For the birth cohorts under study compulsory education (Grundskola) spanned grades 1-9, preceded by non-compulsory but widely attended pre-school.

Upper secondary education is not compulsory. Still, it is a minimum requirement for most jobs (Lundahl \& Olofsson 2014). Grades permitting, almost all young people therefore continue to upper secondary education immediately after completing compulsory education (Statistics Sweden 2017b). Barring a few tracks for highly specialized occupations, students in upper secondary education enter one of several national programs. The national programs are formally separated into vocational and academic programs, but the separation is less strict than in many countries. During the period under study, students who passed enough courses in upper secondary education - including in some central subjects like Swedish and Mathematics - were consequently able to apply to higher education, irrespective of their track.

However, about $12 \%$ of young people lack the qualifications needed to transition from compulsory education into a national program at upper secondary education (Skolinspektionen 2014). These young people are instead referred to preparatory programs - called individual or introductory programs - or to compensatory adult education, depending on their age.

The window for entering a national program in upper secondary closes in the spring term of the year a person turns 20. This sets a hard limit to the time available for young people to complete their upper secondary education. Still, about $75 \%$ of young people in introductory programs and $15 \%$ of young people in national programs do not attain 
an upper secondary diploma within five years of completing compulsory education (Skolverket 2013). Following earlier Swedish research (Cederberg \& Hartsmar 2013; Behtoui et al. 2018), I define this group as early school leavers.

To meet the requirements of the labor market or to gain qualifications for higher education, many early school leavers enter second-chance education (Lundahl et al. 2017). In international comparison Sweden provides extensive options for secondchance education, primarily through municipal adult education (Komvux) or folk high schools (Folkhögskola). But despite the size and importance of second-chance education in Sweden, it is not always included in official statistics (Bäckman et al. 2011). This creates a knowledge gap about early school leavers, and especially how they navigate the transition into the labor market.

\section{Young People with an Immigrant Background}

Almost a quarter of Swedes under 18 years of age have an immigrant background, meaning that both their parents were born outside of Sweden (Statistics Sweden 2017a). 'Immigrant background' is consequently a large and heterogeneous category. In 2000 and 2001, the most common countries of origin were Finland, the Former Yugoslavia, Iraq, and Iran.

Swedish integration policy ranks high in international comparisons (Huddleston et al. 2015). Still, many immigrants struggle to enter the labor market, and children of immigrants are more likely to grow up in poverty (Gustafsson \& Österberg 2018). Immigrants also tend to have lower levels of education compared to non-immigrants, and their children often face further disadvantages in Swedish schools (Brandén et al. 2018; Gustafsson \& Österberg 2018; Behtoui et al. 2019). Consequently, young people with an immigrant background are over-represented among early school leavers (Elffers 2012; Cederberg \& Hartsmar 2013). Young people with an immigrant background also struggle more with entering the labor market than young people with a non-immigrant background, meaning that disadvantages in childhood and education often become more pronounced in the transition from school to work (Brandén et al. 2016).

\section{Theory}

While young people with an immigrant background are overrepresented among early school leavers, immigrant parents are often well-educated relative to their countries of origin and value education highly (Ichou 2014). This translates into high expectations among parents, and high aspirations among their children. Young people with an immigrant background are also sometimes supported by a more resource-rich contact network than their families' current class position would suggest (for overview, see Nygård \& Behtoui 2020). They therefore tend to exhibit high levels of educational and career aspirations, even when studying in disadvantaged schools (Nygård 2017; Feliciano \& Lanuza 2018). Such aspirations and support can in turn be a powerful resource in the school-to-work transitions of early school leavers, leading to better outcomes in both education and the labor market (Schoon \& Duckworth 2010; Holtmann et al. 2017). 
At the same time, young people with an immigrant background are often at a disadvantage in the labor market. As Granovetter showed, people find jobs not just by searching, but also by being directed towards them by others, or by having jobs tailored to them by previously known employers (Granovetter 1995, p. 146). This however depends on having powerful contacts in the local labor market, which immigrant families often lack.

Segregation and discrimination also often work to the disadvantage of young people with an immigrant background, in both education and the labor market (Zschirnt \& Ruedin 2016). The risk of discrimination is related to the possibility of 'passing' as Swedish (i.e., appearing to be Swedish although from an immigrant background), which in turn relates to factors such as socioeconomic status, skin tone, name, and country of origin (Gullestad 2002; Arai \& Thoursie 2009). Research has consequently found a consistent pattern whereby Northern Europeans are less often perceived as 'immigrants' than other Europeans, while people from the Middle East and Africa are more often seen as 'immigrants' (see Myrberg 2010 for an overview). Early school leavers from the Middle East and Africa can consequently be expected to be particularly disadvantaged in the labor market.

Swedish second-chance education does not charge tuition fees and is facilitated through grants and loans. Still, many early school leavers rely on their families for economic and other forms of support (Lundahl et al. 2017). In addition, better access to family resources is generally associated with more beneficial outcomes in both education and the labor market. Parents' class positions, education levels, and social networks consequently influence their offspring's transitions after compulsory education (Dorsett $\&$ Lucchino 2014; Schoon \& Lyons-Amos 2016; Lindblad \& Lundahl 2020). In addition, the types of resources available also influence the type of trajectory a person follows (Strømme 2020). Well-educated parents provide resources that are conducive to more education-oriented trajectories, whereas high-income parents provide information, help, and connections that increase the likelihood of work-oriented trajectories.

Finally, the educational underachievement of boys is well documented across the industrialized countries (Buchmann et al. 2008). One important factor is differences in gender roles and peer norms, in which masculinity is often constructed as opposed to studiousness (Phoenix 2004). Boys are therefore more likely than girls to study vocational programs in upper secondary education, and to leave school early. This pattern is especially pronounced among persons with working-class background (Legewie \& DiPrete 2012). That said, the gender norms around education might make it harder for female early school leavers to find work - especially because jobs that do not require an upper secondary diploma are typically male-dominated (Albæk et al. 2015; Achatz et al. 2020). Because of this, I expect male early school leavers to more often be in workoriented trajectories than female early school leavers.

\section{Previous research}

Lundahl et al. (2017) describe three basic transition patterns for early school leavers in Sweden: (1) into work, (2) into further education, and (3) into alternating short spells of work, participation in training or other youth schemes, and unemployment. However, a key problem for these young adults was that their transitions were often indistinct and 
offered few choices. Entering the labor market was often slow and difficult, and transitions and other important events - such as moving - were seldom self-initiated (Lundahl et al. 2017; Lindblad \& Lundahl 2020). Consequently, while school-to-work transitions have a predictable set of outcomes, for early school leavers they are often extended and lack the clear-cut separation between education, work, and other activities that a timely completion allows.

In a recent study, Lorentzen et al. (2018) used sequence analysis to distinguish between five types of school-to-work trajectories for Swedish young people: short, medium, and long education into work; a turbulent trajectory; and finally an exclusion trajectory. The turbulent trajectory was characterized by frequent shifts between education, unstable workforce affiliation, and being not in employment, education, or training (NEET). The exclusion trajectory was dominated by extended periods of NEET status, commonly following a short initial period of education. Comparing young people with and without an immigrant background, the former were found to have a higher risk of being in the exclusion trajectory.

Previous studies on early school leavers or young people with low educational qualifications also report similar patterns. Young people with an immigrant background and those with well-educated parents tend to be in more education-oriented trajectories as opposed to more work-oriented trajectories (Dorsett \& Lucchino 2014; Achatz et al. 2020). Parents' labor-market attachment, on the other hand, is generally not found to be a major influence. One possible explanation for this is that parents' labor-market attachment is a decisive factor for whether young people become early school leavers in the first place, since studies looking at the full student population have found parents' occupation to be a major predictor of school-to-work trajectories (Schoon \& Lyons-Amos 2016).

A recurring theme in previous studies is also the gendered nature of school-to-work trajectories and transitions. Women are generally found to be over-represented in negative school-to-work trajectories and under-represented in more career-oriented trajectories (Dorsett \& Lucchino 2014; Achatz et al. 2020; Vogt et al. 2020). These gender differences in labor-market entry after early school leaving led Struffolino and Borgna (2020) to conclude that, despite the great concerns expressed over low-achieving boys in the public debate, girls who leave school early are the ones who are really left behind. Such gendered patterns are also found in Sweden. Swedish boys are more likely than girls to leave school early and less likely to complete upper secondary education through secondchance education (Albæk et al. 2015). However, women with low educational qualifications are more likely than men to be unemployed (Statistics Sweden 2018, 2017b).

\section{Data}

I used Swedish population-level registry data on persons from two birth cohorts: 1984 and 1985. The cohorts were chosen on data availability, and to allow for a period without major policy reforms affecting upper secondary education. I selected all the individuals in these cohorts who finished compulsory education during the year they turned 16 (2000 and 2001, respectively), and did not complete upper secondary education within five additional years. To avoid conflating working or living in another country with inactivity, I excluded all cases who had no registered address in Sweden. 
To reflect the varying degrees 'passing' as Swedish, I constructed seven categories based on parents' region of birth: Sweden, North-West, Central and Eastern Europe, Latin America, Middle East and North Africa (MENA), Rest of Asia, and sub-Saharan Africa $^{1}$. Cases with parents from different regions were omitted. All observations with two foreign-born parents, together with a random 5\% sample of the observations with two Sweden-born parents were included. After listwise deletion, this gave a balanced panel of 6404 individuals through 10 years for the sequence analysis (see Table 1). Sample weights were used to account for the sampling procedure. Except for in the descriptive table, estimates, frequencies, and percentages are therefore given for the full cohort population of early school leavers residing in Sweden and with parents born in the same country.

\section{Classification of activities}

For each person in this sample, I used the recorded activity for the first ten years after compulsory school to create individual sequences of events, such as moving from education to unemployment and back to education.

Activities were classified primarily in relation to education, and secondarily in relation to work. I coded every person enrolled in education at any point during a year as studying, distinguishing between the types of education. Individuals not studying were instead coded based on their income. Throughout the procedure, I followed the classifications used in the report series Establishment on the Labor Market (see, e.g., Universitetskanslersämbetet 2015; Högskoleverket 2003). This classification was chosen partly for comparability with official reports, but also because it uses a threshold for labormarket attachment that follows Swedish wage trends more closely than the SELMA model of labor-market attachment used in other studies (Kindlund \& Biterman 2002; Lorentzen et al. 2018). Wage trends are important when tracking income over several years, as failure to do so might otherwise produce the illusion of careers. That said, the threshold for labor-market attachment in both classifications is set very low, corresponding to the earnings from the lowest-paying Swedish jobs (Kindlund \& Biterman 2002). As an alternative, I also fitted models using an earnings threshold corresponding to $80 \%$ of the median income. The different classifications naturally resulted in differently sized clusters. Still, both the cluster typology and regression results were largely similar (compare table A1 in Appendix). Because of this, I will only discuss the main classification.

Concretely, anyone registered as being in education in a given year was coded as being in youth education (including upper secondary education), in second-chance education (including municipal adult education, folk high schools, and preparatory programs at universities), in tertiary education, or in other education (including vocational post-secondary education, and anyone who was not listed as being in education but had income from student loans, grants, or allowances). Academic and vocational programs provide different sets of skills and contacts that might result in different school-to-work trajectories for early school leavers (Vogt et al. 2020). However, to limit complexity I did not distinguish between different programs or fields of study.

Among non-students, those with income from work were coded as established or not established based on whether their earnings were above a threshold or not, set at 155,300 SEK for 2002 (about $€ 16,300$, or approximately $67 \%$ of the median earnings) 
and increasing by approximately $3 \%$ annually to account for the general wage increase. Missing values for 2010 and 2012 were imputed linearly from neighboring years. This gave categories - not established and established - and a final NEET category for those who were not registered in education and had neither earnings nor study-related income. The latter category consequently includes people who have other forms of income, for example from welfare benefits relating to disability, sickness, or unemployment.

\section{Family resources}

To account for family resources, I included variables for parents' income and education at T $=0$ using averages across parents (Thaning \& Hällsten 2020). Parents' class position was proxied through parents' income, calculated as the average of the parents' workrelated income - including transfers and benefits. Parents' educational merits were in turn measured through parents' years of schooling, coded as the years normally needed to complete their respective highest education level and averaged across parents - from no education (0), short compulsory (5), long compulsory (9), short secondary (11), long secondary (12), short tertiary (15), and long tertiary (17) education.

The uneven expansion of education makes cross-country comparisons of educational merits problematic. I therefore also calculated measures of each parents' education rank in relation to their country of origin. Studies have shown that this measure provides a contextualized indicator of status, and is a better predictor of academic outcomes relating to aspirations and educational decisions (Engzell 2019). To account for this, I calculated indicators of education rank as the percentage of the population in the same gender/age bracket in the country of origin with a lower level of education, plus half of the proportion with a similar level of education (Ichou 2014). Reference data was taken from the most recent version of the Barro-Lee data set (Barro and Lee 2013) and the reference year was set to 2000. This resulted in a continuous measure, ranging from just over 0 to just under 100 , which can be understood as the percentile rank of the parents' education. For sedentary families in the same generation, the correlation between years of schooling and education rank is almost perfect. Because of this, the measures are only used in separate models.

\section{Other variables}

As discussed above, women in contemporary Sweden are generally more academically oriented than men. Both program choices at upper secondary level and the rates of early school leaving consequently differ by gender. School-to-work transitions among early school leavers, on the other hand, are typically swifter for men than for women (Albæk et al. 2015; Struffolino \& Borgna 2020). Gender is consequently an important factor in the trajectories of early school leavers. Because of this, I included a variable for gender.

Labor-market participation is higher among early school leavers with qualifications for upper secondary education than among those without (Statistics Sweden 2018). To control for previous educational attainment, I used grades from the final year of compulsory school as a percentage of the maximum possible grades. I also included control variables for birth year, to account for cohort-specific factors. Finally, to illustrate the labor-market outcomes of the various trajectories, I used earnings at age 26 ( $T=10)$. 


\section{Method}

The analysis was performed in two steps. In the first step, I used sequence analysis to assess similarities and dissimilarities among the transitions and states. Sequence analysis provides a way of studying individual events and transitions in the context of the events and transitions that surround them through time. The specific sequences under study in turn point towards the person's trajectory over their life course, consisting of the interplay between the structured pathways through institutions and the social trajectories of individuals (Elder 1994; Brzinsky-Fay 2007).

I calculated a dissimilarity matrix for each person's sequence of events using SQ.ado (Kohler et al. 2006). Calculating differences involves a choice between the ordering and the timing of events. Using high substitution costs means giving priority to the order of events, whereas high indel costs instead gives priority to timing (Lesnard 2010). Following previous research (Lorentzen et al. 2018), I see order as more critical than timing in the transition from school to work. Transition periods might be extended or contracted in time, but there are strong normative expectations that each type of event should be followed by certain other events - for example that unemployment should be followed by employment, and not vice versa. Because of this, I used substitution costs that were double the indel costs, meaning that the calculation of dissimilarities is effectively based on the longest common subsequences (Lesnard 2010).

The resulting dissimilarity matrix was subsequently used to group the individual transitions into clusters containing young adults with similar sequences, using Ward's linkage. While there is no objectively 'true' number of clusters (Aisenbrey \& Fasang 2010), I settled on a four-cluster solution supported by the highest average silhouette width (Rousseeuw 1987). Due to the small number of clusters, each cluster contain substantial heterogeneity. Still, because of the high substitution costs used when assessing dissimilarity, all clusters share substrings of states and events. Cluster membership can consequently be understood as an indicator of a certain type of transition pattern, or trajectory.

In the second step, I used multinomial logit regressions to estimate the predictors of being in each trajectory, using cluster membership as the dependent variable. To account for school segregation, which might affect opportunities through systematic differences in friendship formations, teaching quality, local labor markets, etc., robust standard errors were calculated and clustered by compulsory school. All models also included sampling weights to correct for the sampling procedure.

Immigrant background, class and gender often intersect in non-additive ways (McCall 2005). For example, research has found that discrimination patterns in the labor market are different for men than for women (Arai et al. 2016). I tested for this through interaction models, but found no substantial interaction effects. I therefore excluded interaction terms from the final models.

\section{Results}

Descriptive statistics are presented in Table 1. The table shows that the average early school leaver had grades from compulsory education that were lower than $50 \%$. Given the disproportionate weighting of a pass grade in the Swedish grading system, a grade

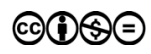


below $50 \%$ means that one or more subjects had not been passed. As discussed above, this limits the choices available after compulsory school, highlighting that early school leaving is often just one moment in a longer series of events.

Table I Descriptive statistics for Swedish early school leavers by parents' region of birth

\begin{tabular}{lccccccc}
\hline & Sweden & $\begin{array}{c}\text { North- Central/ } \\
\text { West } \\
\text { East } \\
\end{array}$ & $\begin{array}{c}\text { Europe } \\
\text { America }\end{array}$ & $\begin{array}{c}\text { Latin } \\
\text { AmENA }\end{array}$ & $\begin{array}{c}\text { Rest } \\
\text { of } \\
\text { Asia }\end{array}$ & $\begin{array}{c}\text { Sub- } \\
\text { Saharan } \\
\text { Africa }\end{array}$ \\
\hline Grades, percent & 46.86 & 43.40 & 42.83 & 41.95 & 41.81 & 41.20 & 43.43 \\
& $(20.33)$ & $(21.71)$ & $(22.31)$ & $(20.32)$ & $(23.66)$ & $(21.65)$ & $(21.84)$ \\
\hline Parents' income, 100,000 SEK & $1.87 \mid$ & 1.337 & 0.965 & 1.251 & 0.597 & 0.702 & 0.814 \\
& $(1.105)$ & $(1.028)$ & $(1.089)$ & $(0.846)$ & $(0.797)$ & $(0.696)$ & $(0.808)$ \\
\hline Parents' years of schooling & $\mid 1.75$ & 10.17 & 10.48 & 10.93 & 10.12 & 8.571 & 10.30 \\
& $(2.243)$ & $(2.612)$ & $(2.915)$ & $(2.436)$ & $(3.343)$ & $(2.808)$ & $(2.859)$ \\
\hline Parents' education rank & 38.89 & 34.86 & 38.25 & 53.18 & 66.98 & 51.97 & 84.43 \\
& $(23.99)$ & $(21.97)$ & $(26.26)$ & $(20.74)$ & $(20.59)$ & $(24.37)$ & $(12.19)$ \\
\hline Women & $41.3 \%$ & $42.8 \%$ & $42.2 \%$ & $45.7 \%$ & $40.0 \%$ & $41.1 \%$ & $41.2 \%$ \\
\hline Observations & 1403 & 970 & 1223 & 442 & 1419 & 721 & 226 \\
\hline
\end{tabular}

Percentage shares or means with standard deviation in parentheses. $N=6404$.

Previous studies have found that the overrepresentation of young people with an immigrant background among early school leavers can largely be attributed to socio-economic factors (Elffers 2012). This explanation is also suggested by the substantial difference in parents' income between early school leavers depending on their parents' region of birth. Parents born in Sweden had more than double the average work-related income than parents from Rest of Asia or sub-Saharan Africa, and three times higher than parents from MENA countries (see also Gustafsson \& Österberg 2018). Swedish early school leavers thus come from homes with vastly different levels of income, depending on where their parents were born.

Furthermore, the table shows that the average early school leavers had parents with less than 12 years of schooling, signifying incomplete merits from upper secondary education. Education was especially short among parents born in Rest of Asia, with an average of less than nine years of education. However, a problem with these measures is that educational systems differ between countries, and that educational merits are not always fully recognized. What is recognized as a 'long' education under one system might consequently be considered 'short' under another (Feliciano \& Lanuza 2017). If education is instead considered relative to the country of origin, a different pattern emerges. Parents of early school leavers born in Sweden, the North-West, or Central/Eastern Europe had an average education rank substantially below 50. This means that these parents were considerably lower educated than the average in their respective country of birth. Parents of early school leavers from the Middle East, North Africa or sub-Saharan Africa, on the other hand, were well-educated relative to their respective countries of birth (see also Engzell 2019). Even if their educational merits were limited in the Swedish context, they might consequently still benefit from other assets, such as expectations, 
dispositions, and embodied cultural capital (Bourdieu 1986) that are helpful for their children. Parents' education rank for early school leavers in the Latin America and Rest of Asia categories were, in turn, similar and close to the median, despite the substantial difference in years of education between these two categories.

\section{School-to-work trajectories of early school leavers}

Despite having left upper secondary school, many of the early school leavers under study were still in education. This highlights that for the vast majority of people, early school leaving is a passing event, rather than an end state (Van Caudenberg et al. 2017). Still, a key characteristic of school-to-work transitions is the degree of linearity, or the correspondence between the actual and the normatively expected order of events (BrzinskyFay \& Solga 2016). To take this into account, I performed a sequence analysis to assess similarities and dissimilarities in the order of events. The resultant sequences were then clustered into four school-to-work trajectories, presented in Figure 1.

In the first cluster, NEET was the dominating status in all years after leaving school. As discussed above, this group includes both unemployed and people who are prevented from working by poor health or disabilities. Due to the high prevalence of NEET status

Figure I Sequence percentage plots for the four principal clusters of school-to-work trajectories found among Swedish early school leavers born in 1984 and 1985.

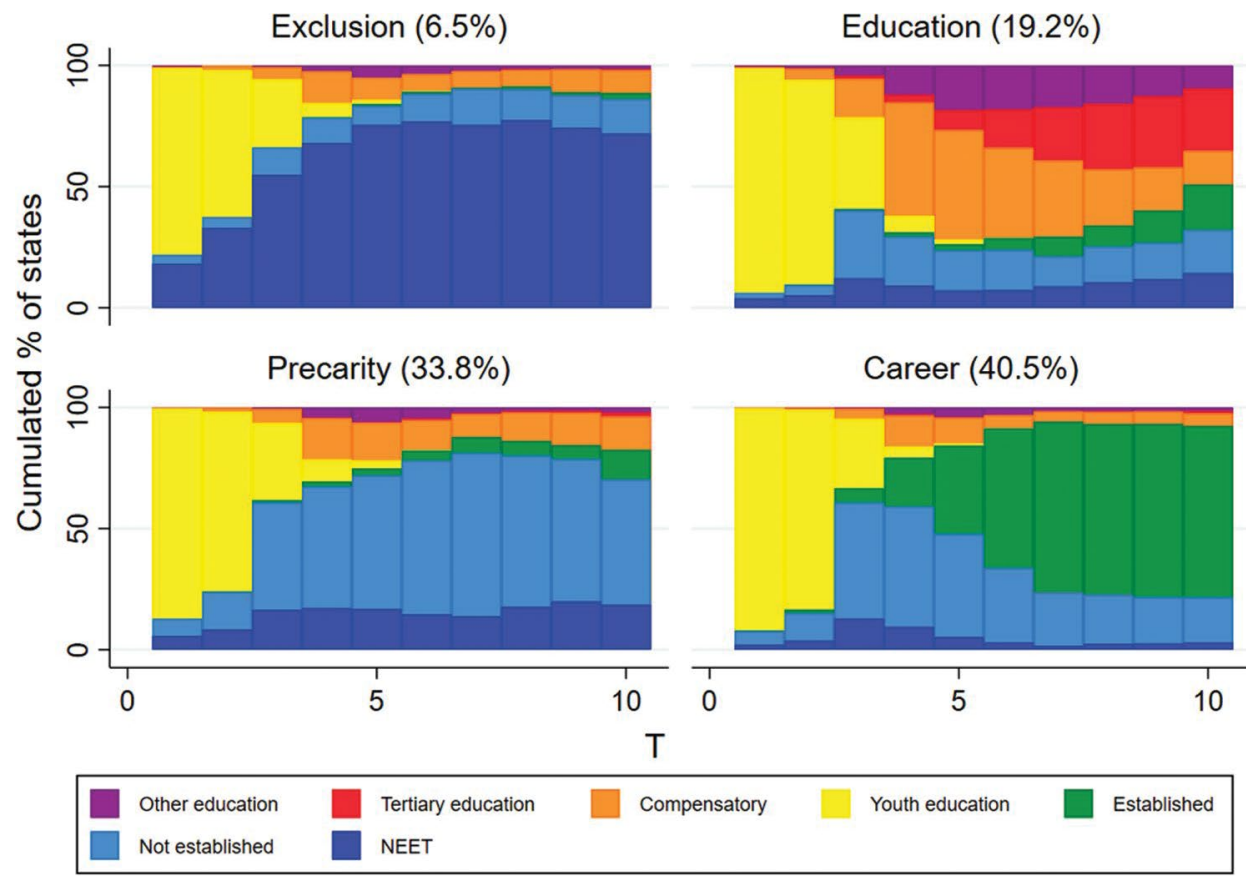

Cumulative percentage of individuals in each state ( $y$-axis) and years after compulsory school ( $x$-axis). Weighted percentage share of early school leavers in each cluster in parentheses after cluster name. 
in this cluster I call it the exclusion trajectory, even if the reasons for exclusions vary. This trajectory represented a sizeable proportion of young people but was the least common.

The second cluster was characterized by a large percentage of second-chance and other education. In addition, the cluster also contained a sizable and growing share of people in tertiary education. Because of this, I refer to this cluster as the education trajectory. The education cluster was the second smallest, but still accounted for about a fifth of the early school leavers in the birth cohorts.

The third cluster accounted for more than a third of the early school leavers in the two cohorts. Young adults in this cluster entered the labor market quickly, but largely failed to become established throughout the period under study. Instead, most had persistently low earnings, indicating part-time employment, spells of unemployment, or both. Therefore, this cluster can be described as a precarity trajectory.

The fourth and largest cluster, finally, was the most work oriented. Young adults in this group rose quickly from not established to established after leaving school. The modal person in this cluster was established within four years of leaving youth education, meaning that their speed of establishment is comparable to young people completing upper secondary education. In light of this, I call this cluster the career trajectory. Somewhat surprisingly, this trajectory was most common, and accounted for about $40 \%$ of the early school leavers. That said, it should be noted that the size of this cluster is highly dependent on the earnings threshold used to indicate being established. Setting a higher threshold naturally shifts the balance between the precarity and career trajectories (compare figure A1 in Appendix). Still, it is clear that a large share early school leavers find ways to become established in the labor market at a similar pace to non-leavers.

The school-to-work trajectories are summarized in Table 2. To place these trajectories in perspective, the median and mean earnings at age 26 for each trajectory can be compared to those of young adults in the birth cohorts who completed upper secondary education. As seen in the table, the median earnings among non-leavers in the birth cohorts was 206,000 SEK. This is more than 50,000 SEK below the median earnings in the career trajectory, meaning that many early school leavers were doing well in the labor market, at least in the short-to-medium term.

Table 2 Summary of the four clusters of school-to-work trajectories and non-leavers for comparison

\begin{tabular}{llc}
\hline Trajectory & Characteristics & $\begin{array}{c}\text { Median (mean) } \\
\text { earnings age 26 }\end{array}$ \\
\hline $\begin{array}{l}\text { Exclusion } \\
6.5 \%\end{array}$ & Persistently high degree of NEET status after leaving youth education. & $\begin{array}{c}0 \text { SEK } \\
(20,000 ~ S E K)\end{array}$ \\
\hline Education & Education-oriented. Second-chance education combined with other & 56,000 SEK \\
$19.2 \%$ & forms of non-tertiary education and training, followed by tertiary & $(104,000$ SEK) \\
& education. Gradually increasing levels of labor-market attachment. & \\
\hline Precarity & Work-oriented. Some second-chance education or training. Persis- & 70,000 SEK \\
$33.8 \%$ & tently low degree of attachment to the labor market. & $(93,000$ SEK $)$ \\
\hline Career & Work-oriented. Little second-chance education or training. Initially Steadily & 262,000 SEK \\
$40.5 \%$ & increasing attachment to the labor market after leaving youth education. & $(244,000$ SEK $)$ \\
\hline Non-leavers & (comparison) & 206,000 SEK \\
& & $(193,000$ SEK $)$ \\
\hline
\end{tabular}

Percentage share weighted for sampling procedure. Median (mean) annual earnings at age $26(T=10)$. 


\section{Predictors of school-to-work trajectories}

For all early school leavers in the birth cohorts under study, more than $40 \%$ were in the career trajectory, while approximately $19 \%$ were in the education trajectory. However, as discussed above, there are reasons to expect that there are systematic differences in which school-to-work trajectory early school leavers follow, depending on their migration background, family resources, and gender. To study this, I fitted multinomial logistic regressions to estimate the predictors of each school-to-work trajectory. The results are presented in Table 3.

The results show that early school leavers with foreign-born parents had an equal or higher probability of being in the education trajectory than early school leavers with parents born in Sweden. Early school leavers with parents born in sub-Saharan Africa or MENA were especially likely to be in this trajectory.

Table 3 Predictors of school-to-work trajectory for young adults who left school without completing upper secondary education

\begin{tabular}{|c|c|c|c|c|}
\hline & Exclusion & Education & Precarity & Career \\
\hline \multicolumn{5}{|c|}{ Parents' region of birth (ref: Sweden) } \\
\hline \multirow[t]{2}{*}{ North-West } & 0.02 & -0.01 & 0.05 & $-0.06^{*}$ \\
\hline & $(0.01)$ & $(0.02)$ & $(0.02)$ & $(0.02)$ \\
\hline \multirow[t]{2}{*}{ Central/East Europe } & 0.01 & $0.05^{* * *}$ & 0.01 & $-0.07^{* * *}$ \\
\hline & $(0.01)$ & $(0.02)$ & $(0.02)$ & $(0.02)$ \\
\hline \multirow[t]{2}{*}{ Latin America } & -0.00 & $0.08^{* * *}$ & $0.12^{* * *}$ & $-0.19^{* * *}$ \\
\hline & $(0.01)$ & $(0.02)$ & $(0.03)$ & $(0.02)$ \\
\hline \multirow[t]{2}{*}{ MENA } & 0.01 & $0.16^{* * *}$ & 0.03 & $-0.20^{* * *}$ \\
\hline & $(0.01)$ & $(0.02)$ & $(0.03)$ & $(0.02)$ \\
\hline \multirow[t]{2}{*}{ Rest of Asia } & $-0.02^{*}$ & $0.11^{* * *}$ & $0.08^{*}$ & $-0.17^{* * * *}$ \\
\hline & $(0.01)$ & $(0.03)$ & $(0.03)$ & $(0.02)$ \\
\hline \multirow[t]{2}{*}{ Sub-Saharan Africa } & $0.06^{*}$ & $0.24^{* * *}$ & -0.02 & $-0.28^{* * *}$ \\
\hline & $(0.02)$ & $(0.05)$ & $(0.04)$ & $(0.03)$ \\
\hline \multirow[t]{2}{*}{ Parents' income, I00k SEK } & $-0.0 I^{*}$ & 0.01 & -0.01 & 0.02 \\
\hline & $(0.01)$ & $(0.01)$ & $(0.02)$ & $(0.02)$ \\
\hline \multirow[t]{2}{*}{ Parents' years of schooling } & -0.00 & $0.03^{* * *}$ & -0.00 & $-0.02^{* * *}$ \\
\hline & $(0.00)$ & $(0.00)$ & $(0.01)$ & $(0.01)$ \\
\hline \multirow[t]{2}{*}{ Woman } & $0.02^{*}$ & $0.08^{* * *}$ & $0.18^{* * *}$ & $-0.28^{* * *}$ \\
\hline & $(0.01)$ & $(0.02)$ & $(0.02)$ & $(0.02)$ \\
\hline Observations & 6404 & 6404 & 6404 & 6404 \\
\hline
\end{tabular}

Average marginal effects from weighted multinomial logistic regression. Models control for grades from compulsory school and birth year. Robust standard errors, clustered by schools. $N=6404 .{ }^{*} p<0.05, * * p<0.01, * * * p<0.001$. 
The opposite was true for the career trajectory. Having foreign-born parents was associated with a lower probability of being in the career trajectory than having parents born in Sweden. The largest negative association was found for sub-Saharan Africa, followed by MENA, Latin America and Rest of Asia. These findings consequently closely mirror the discrimination patterns reported in previous research (Myrberg 2010; Ahmadi et al. 2016).

Having foreign-born parents from Latin America or Rest of Asia was associated with a higher likelihood with being in the precarity trajectory compared to having parents born in Sweden, whereas having parents from sub-Saharan Africa was associated with a higher likelihood of being in the exclusion trajectory. Early school leavers with foreign-born parents from Rest of Asia was instead somewhat less likely to be in the exclusion trajectory than early school leavers with parents born in Sweden.

Parents' income was negatively associated with being in the exclusion trajectory, but otherwise not significantly associated with any trajectory. Having parents who were well established in the labor market thus seems to primarily be a protective factor, preventing from NEET status. Parents' years of schooling, on the other hand, was positively associated with the education trajectory, but negatively associated with the career trajectory. This suggests that access to different types of parental resources facilitate different types of trajectories in school-to-work transitions.

Gender, finally, was a strong predictor of school-to-work trajectory. The probability of being in the precarity, education, and exclusion trajectories were higher for women than for men, while the probability of being in the career trajectory was substantially lower. In fact, gender was the most important predictor of being or not being in the career trajectory, but also the most important predictor of being or not being in the precarity trajectory. This is in line with results from other countries, reporting that female early school leavers struggle more than male early school leavers in the labor market (Dorsett \& Lucchino 2014; Achatz et al. 2020; Struffolino \& Borgna 2020).

\section{Parents' education rank and school-to-work trajectories}

Previous research has found that years of schooling can be a misleading indicator of parents' education, especially when comparing between countries. I therefore refitted the same multinomial logistic model while replacing parents' years of schooling with parents' education rank. Overall, using education rank instead of years of schooling resulted in similar estimates. The major exception was in the estimates for parents' region of birth, highlighted in Figure 2.

Using education rank, instead of years of schooling, explained all the variation between early school leavers with parents born in different regions in the education trajectory. Meanwhile, it did not substantially alter the associations between parents' region of origin and any of the other trajectories. This indicates that education rank is a better predictor than years of education for early school leavers propensity of returning to education, highlighting the connection between pre-migration factors and post-migration educational outcomes (Nygård 2021). However, it also highlights how these factors do not translate into similar advantages in the labor market. 
Figure 2 Associations between trajectory and parents' region of birth.

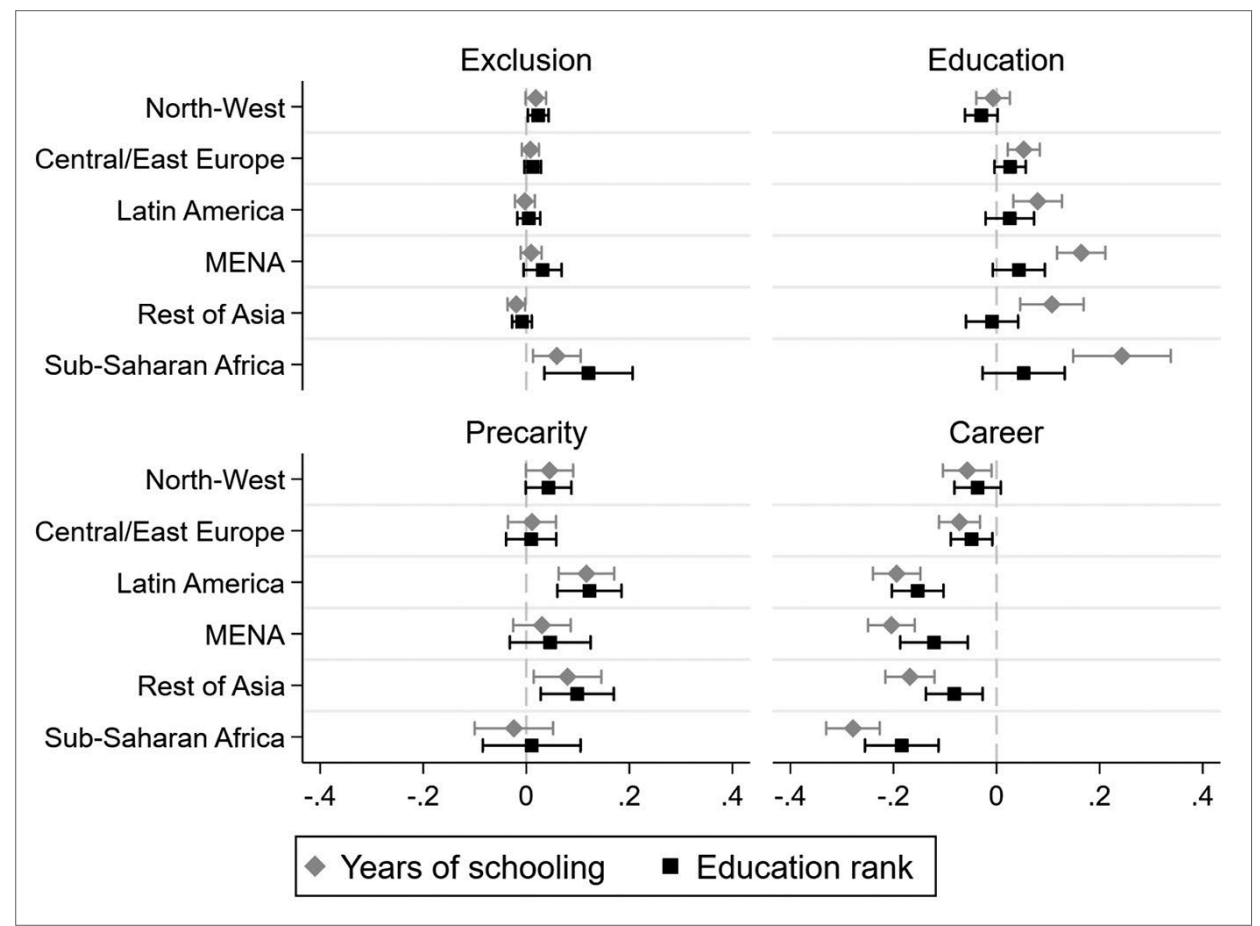

Average marginal effects from weighted multinomial logistic models, using either years of schooling or education rank as measures of parents' education level. 95\% confidence intervals.

\section{Concluding Discussion}

In this article, I have addressed a gap in previous research by studying the school-to-work trajectories of Swedish early school leavers from the 1984 and 1985 birth cohorts, following their activities for 10 years after compulsory education. Using sequence analysis, I distinguished four principal school-to-work trajectories: (1) exclusion, (2) education, (3) precarity, and (4) career. In sharp contrast to what the public discourse suggests, a majority of the early school leavers were in trajectories leading to work, education, or both. This highlights that early school leaving is not an end state, but rather a passing event in a longer trajectory that often includes a return to education (Van Caudenberg et al. 2017). This makes terms such as 'dropouts' or 'early school leavers' potentially misleading, highlighting that many early leavers might be better understood as 'late finishers' (Vogt et al. 2020).

Still, many early school leavers were in the precarity trajectory, characterized by a persistently low degree of labor-market attachment. This could reflect structural factors, such as informalization of the labor market and increasing levels of precariousness in general, and for immigrant families in particular (Likic-Brboric et al. 2013).

Young people with an immigrant background are often found to exhibit high levels of educational aspiration (Engzell 2019). On the other hand, they are more likely to 
face discrimination (Zschirnt \& Ruedin 2016) and lack established contacts in the local labor market that can help with finding a job (Behtoui 2008; Jonsson \& Rudolphi 2011; Zschirnt \& Ruedin 2016; Roth 2018). For these reasons, I expected early school leavers with an immigrant background to be over-represented in education-oriented trajectories, but early school leavers with non-immigrant background to have stronger labormarket attachment.

The results were in line with these predictions. Having foreign-born parents from sub-Saharan Africa, MENA, Latin America, Rest of Asia, or Central and Eastern Europe was associated with a higher likelihood of being in the education trajectories, compared to having parents born in Sweden. On the other hand, having foreign-born parents was associated with a lower likelihood of being in the career trajectory compared to having parents born in Sweden. Early school leavers with foreign-born parents from sub-Saharan Africa was especially unlikely to be in the career trajectory, followed by early school leavers with foreign-born parents from MENA, Latin America, and Rest of Asia. This repeats the patterns of bias against immigrant groups reported in previous research (Myrberg 2010; Ahmadi et al. 2016), further suggesting that discrimination is a factor. Still, a limitation of the present study is that early school leavers with parents from different regions were excluded. More research is therefore needed to understand the transitions of this growing category of young people, that may be differently affected by discrimination.

Having parents with a higher income was associated with a lower risk of being in the exclusion trajectory. Having parents with higher levels of education was instead associated with a higher likelihood of being in the education trajectory, but a lower chance of being in the career trajectory. The relationships between parental resources and the trajectories could thus be understood as reflecting micro-class reproduction (Jonsson et al. 2009), whereby younger generations tend to reproduce the specific composition of cultural and economic capital of older generations. Importantly, parents' education rank - indicating their pre-migration status - could fully account for the increased likelihood of being in the education trajectory for early school leavers with an immigrant background. Parents' education therefore seems to be a resource for early school leavers' school-to-work trajectories, primarily through expectations and attitudes towards education, owing to (past) status positions and embodied cultural capital.

Finally, there were also substantial differences between young men and young women, with the career trajectory being predominantly both non-migrant and male. Early school leavers consequently face vastly different prospects in the labor market depending on their backgrounds, parental resources, and gender. For young men with a non-immigrant background, leaving education early can be a path to rapid labor-market establishment, and a good income.

Considering the heterogeneity within the school-to-work trajectories, future research should focus on both the idiosyncrasies of each type of trajectory and the variation within them. Long-term research is also needed to follow up what happens to school leavers after another 10 years, by which time factors such as family formation and lifetime income can be more clearly estimated. The limitation to two birth years also makes it impossible to study time trends in this article. Another avenue for further research is therefore to make comparisons over time, or to employ designs better suited to studying the role of institutional factors in shaping trajectories. 


\section{References}

Achatz, J., Jahn, K. \& Schels, B. (2020). On the non-standard routes: vocational training measures in the school-to-work transitions of lower-qualified youth in Germany, Journal of Vocational Education \& Training: 1-22. doi: https://doi.org/10.1080/13636820.2020. 1760335.

Ahmadi, F., Palm, I. \& Ahmadi, N. (2016). Mångfaldsbarometern 2016. FOU-rapport 44 [The Diversity Barometer 2016. Research and Development Report 44], Gävle: Gävle University Press.

Aisenbrey, S., \& Fasang, A. E. (2010). New Life for Old Ideas: The 'Second Wave' of Sequence Analysis Bringing the 'Course' Back Into the Life Course, Sociological Methods \& Research 38(3): 420-462. doi: https://doi.org/10.1177/0049124109357532.

Albæk, K., Asplund, R., Barth, E., Lindahl, L., von Simson, K., \& Vanhala, P. (2015). Youth unemployment and inactivity: A comparison of school-to-work transitions and labour market outcomes in four Nordic countries. TemaNord 2015: 548, Copenhagen: Nordic Council of Ministers.

Arai, M., Bursell, M., \& Nekby, L. (2016). The Reverse Gender Gap in Ethnic Discrimination: Employer Stereotypes of Men and Women with Arabic Names, International Migration Review 50(2): 385-412. doi: https://doi.org/10.1111/imre.12170.

Arai, M., \& Thoursie, P. S. (2009). Renouncing Personal Names: An Empirical Examination of Surname Change and Earnings, Journal of Labor Economics 27(1): 127-147. doi: https://doi.org/10.1086/593964.

Bäckman, O., Jakobsen, V., Lorentzen, T., Österbacka, E., \& Dahl, E. (2011). Dropping out in Scandinavia: Social Exclusion and Labour Market Attachment among Upper Secondary School Dropouts in Denmark, Finland, Norway and Sweden. Arbetsrapport 2011: 8, Stockholm: The Institute for Future Studies.

Barro, R., \& Lee, J.-W. (2013). A New Data Set of Educational Attainment in the World, 1950-2010, Journal of Development Economics 104: 184-98. doi: https://doi.org/ 10.1016/j.jdeveco.2012.10.001.

Behtoui, A. (2008). Informal Recruitment Methods and Disadvantages of Immigrants in the Swedish Labour Market, Journal of Ethnic and Migration Studies 34(3): 411-30. doi: https://doi.org/10.1080/13691830701880251.

Behtoui, A., Björklöf, M., \& Strömberg, I. (2018). The Social Relations and Educational Expectations of Young People in Marginalised Areas: Evidence from Sweden. In Comparative Perspectives on Early School Leaving in the European Union, Vol. 1, edited by Lore van Praag, Ward Nouwen, Rut van Caudenberg, Noel Clycq and Christiane Timmerman. London: Routledge.

Behtoui, A., Hertzberg, F., Jonsson, R., Rosales, R. L., \& Neergaard, A. (2019). Sweden: The Otherization of the Descendants of Immigrants. In The Palgrave Handbook of Race and Ethnic Inequalities in Education, edited by Peter A. J. Stevens and A. Gary Dworkin, 1001-37, London: Palgrave Macmillan.

Berggren, C. (2013). The Influence of Gender, Social Class and National Background on Education and Work Career?, Nordic Journal of Migration Research 3(3): 135-44. doi: https://doi.org/10.2478/njmr-2013-0005.

Bourdieu, P. (1986). The Forms of Capital. In Handbook of Theory and Research for the Sociology of Education, edited by John G. Richardson, 241-258, New York: Greenwood.

Brandén, M., Birkelund, G. E., \& Szulkin, R. (2018). Ethnic Composition of Schools and Students' Educational Outcomes: Evidence from Sweden, International Migration Review 53(2): 486-517. doi: https://doi.org/10.1177/0197918318769314.

Brandén, M., Hällsten, M., \& Szulkin, R. (2016). The Intergenerational Transmission of Disadvantage: Education and Labor Market Gaps Between Children of Natives and 
Children of Immigrants. Department of Sociology Working Paper, Stockholm: Stockholm University.

Bratsberg, B., Nyen, T., \& Raaum, O. (2019). Adult Vocational Qualifications Reduce the Social Gradient in Education, Social Inclusion 7(3): 95-109. doi: https://doi.org/10.17645/ si.v7i3.2026.

Brzinsky-Fay, C. (2007). Lost in Transition? Labour Market Entry Sequences of School Leavers in Europe, European Sociological Review 23(4): 409-22. doi: https://doi.org/10.1093/ esr/jcm011.

Brzinsky-Fay, C. (2014). The Measurement of School-to-work Transitions as Processes, European Societies 16(2): 213-32. doi: https://doi.org/10.1080/14616696.2013.821620.

Brzinsky-Fay, C., \& Solga, H. (2016). Compressed, postponed, or disadvantaged? Schoolto-work-transition patterns and early occupational attainment in West Germany, Research in Social Stratification and Mobility 46: 21-36. doi: https://doi.org/10.1016/ j.rssm.2016.01.004.

Buchmann, C., DiPrete, T. A., \& McDaniel, A. (2008). Gender Inequalities in Education, Annual Review of Sociology 34: 319-37. doi: https://doi.org/10.1146/annurev.soc.34. 040507.134719 .

Cederberg, M., \& Hartsmar, N. (2013). Some Aspects of Early School Leaving in Sweden, Denmark, Norway and Finland, European Journal of Education 48(3): 378-389. doi: https://doi.org/10.1111/ejed.12036.

Côté, J. E. (2014). The Dangerous Myth of Emerging Adulthood: An Evidence-Based Critique of a Flawed Developmental Theory, Applied Developmental Science 18(4): 177-188. doi: https://doi.org/10.1080/10888691.2014.954451.

Dorsett, R., \& Lucchino, P. (2014). Explaining patterns in the school-to-work transition: An analysis using optimal matching, Advances in Life Course Research 22: 1-14. doi: https:// doi.org/10.1016/j.alcr.2014.07.002.

Elder, G. H. (1994). Time, Human Agency, and Social Change: Perspectives on the Life Course, Social Psychology Quarterly 57(1): 4-15.

Elffers, L. (2012). One foot out the school door? Interpreting the risk for dropout upon the transition to post-secondary vocational education, British Journal of Sociology of Education 33(1): 41-61. doi: https://doi.org/10.1080/01425692.2012.632866.

Engzell, P. (2019). Aspiration Squeeze: The Struggle of Children to Positively Selected Immigrants, Sociology of Education 92(1): 83-103. doi: https://doi.org/10.1177/00380 40718822573.

Feliciano, C., \& Lanuza, Y. R. (2017). An Immigrant Paradox? Contextual Attainment and Intergenerational Educational Mobility, American Sociological Review 82(1): 211-41. doi: https://doi.org/10.1177/0003122416684777.

Feliciano, C., \& Lanuza, Y. R. (2018). The Immigrant Advantage in Adolescent Educational Expectations, International Migration Review 50(3): 758-92. doi: https://doi.org/10.1111/ imre.12183.

Granovetter, M. (1995). Getting a Job: A Study of Contacts and Careers. 2nd ed., Chicago: University of Chicago Press.

Gullestad, M. (2002). Invisible Fences: Egalitarianism, Nationalism and Racism, The Journal of The Royal Anthropological Institute 1(8): 45-63. doi: https://doi.org/10.1111/14679655.00098.

Gustafsson, B., \& Österberg, T. (2018). How are Immigrant Children in Sweden Faring? Mean Income, Affluence and Poverty Since the 1980s, Child Indicators Research 11(1): 329-353. doi: https://doi.org/10.1007/s12187-016-9416-9.

Högskoleverket (2003). Etableringen på arbetsmarknaden. Högskoleverkets rapportserie 2003: 7 R [Establishment in the labour market. Reports from the Swedish National Agency for Higher Education 2003: 7 R], Stockholm: Högskoleverket. 
Holtmann, A. C., Menze, L, \& Solga, H. (2017). Persistent Disadvantages or New Opportunities? The Role of Agency and Structural Constraints for Low-Achieving Adolescents' School-to-Work Transitions, Journal of Youth and Adolescence 46(10): 2091-2113. doi: https://doi.org/10.1007/s10964-017-0719-z.

Huddleston, T., Bilgili, O., Joki, A.-L., \& Vankova, Z. (2015). Migrant Integration Policy Index 2015.

Ichou, M. (2014). Who They Were There: Immigrants' Educational Selectivity and Their Children's Educational Attainment, European Sociological Review 30(6): 750-765. doi: https://doi.org/10.1093/esr/jcu071.

Jonsson, J. O., Grusky, D. B., Di Carlo, M., Pollak, R., \& Brinton, M. C. (2009). Microclass Mobility: Social Reproduction in Four Countries, American Journal of Sociology 114(4): 977-1036. doi: https://doi.org/10.1086/596566.

Jonsson, J. O., \& Rudolphi, F. (2011). Weak Performance-Strong Determination: School Achievement and Educational Choice among Children of Immigrants in Sweden, European Sociological Review 27(4): 487. doi: https://doi.org/10.1093/esr/jcq021.

Kindlund, H., \& Biterman, D. (2002). Chapter 3. Work and the labour market, International Journal of Social Welfare 11: S16-S40. doi: https://doi.org/10.1111/1468-2397.11.s3.4.

Kohler, U., Luniak, M., \& Brzinsky-Fay, C. (2006). SQ: Stata module for sequence analysis. Boston College Department of Economics.

Legewie, J., \& DiPrete, T. A. (2012). School Context and the Gender Gap in Educational Achievement, American Sociological Review 77(3): 463-85. doi: https://doi.org/10.1177/ 0003122412440802.

Lesnard, L. (2010). Setting Cost in Optimal Matching to Uncover Contemporaneous Socio-Temporal Patterns, Sociological Methods \& Research 38(3): 389-419. doi: https:// doi.org/10.1177/0049124110362526.

Likic-Brboric, B., Slavnic, Z., \& Woolfson, C. (2013). Labour migration and informalisation: East meets West, International Journal of Sociology and Social Policy 33(11/12): 677-92. doi: https://doi.org/10.1108/ijssp-10-2012-0087.

Lindblad, M., \& Lundahl, L. (2020). Winding Paths through School and After: Young Swedes of Migrant Origin Who Failed in Upper Secondary School. In Youth on the Move: Tendencies and Tensions in Youth Policies and Practices, edited by Kristiina Brunila and Lisbeth Lundahl, 79-99, Helsinki: Helsinki University Press.

Lorentzen, T, Bäckman, O., Ilmakunnas, I., \& Kauppinen, T. (2018). Pathways to Adulthood: Sequences in the School-to-Work Transition in Finland, Norway and Sweden, Social Indicators Research 141(3): 1285-305. doi: https://doi.org/10.1007/s11205018-1877-4.

Lundahl, L., Lindblad, M., Lovén, A., Mårald, G., \& Svedberg, G. (2017). No particular way to go, Journal of Education and Work 30(1): 39-52. doi: https://doi.org/10.1080/13639 $\underline{080.2015 .1122179 .}$.

Lundahl, L., \& Olofsson, J. (2014). Guarded transitions? Youth trajectories and school-towork transition policies in Sweden, International Journal of Adolescence and Youth 19 (sup 1): 19-34. doi: https://doi.org/10.1080/02673843.2013.852593.

McCall, L. (2005). The Complexity of Intersectionality, Signs 30(3): 1771-800. doi: https:// doi.org/10.1086/426800.

Middeldorp, M. M., Edzes, A. J. E, \& van Dijk, J. (2019). Smoothness of the School-to-Work Transition: General versus Vocational Upper-Secondary Education, European Sociological Review 35(1): 81-97. doi: https://doi.org/10.1093/esr/jcy043.

Mood, C. (2010). Logistic Regression: Why We Cannot Do What We Think We Can Do, and What We Can Do About It, European Sociological Review 26(1): 67-82. doi: https://doi. org/10.1093/esr/jcp006. 
Myrberg, G. (2010). Who is an Immigrant? In Diversity, Inclusion and Citizenship in Scandinavia, edited by Bo Bengtsson, Per Strömblad and Ann-Helén Bay, 47-74, Newcastle upon Tyne: Cambridge Scholars Publishing.

Nygård, O. (2017). Early tracking and immigrant optimism: a comparative study of educational aspirations among students in disadvantaged schools in Sweden and the Netherlands, Comparative Migration Studies 5(1): 20. doi: https://doi.org/10.1186/ s40878-017-0063-1.

Nygård, O. (2021). Pre-Migration Status, Social Capital, and the Educational Aspirations of Children of Immigrants in Disadvantaged Swedish Schools, Scandinavian Journal of Educational Research: 1-14. doi: https://doi.org/10.1080/00313831.2021. 1897878.

Nygård, O., \& Behtoui, A. (2020). Access to Social Capital and Educational Returns for Children of Immigrants: Evidence from Three Swedish Studies, Nordic Journal of Migration Research 10(2): 50-66. doi: https://doi.org/10.33134/njmr.248.

Phoenix, A. (2004). Neoliberalism and Masculinity, Youth \& Society 36(2): 227-46. doi: https://doi.org/10.1177/0044118x04268377.

Roth, T. (2018). The influence of parents' social capital on their children's transition to vocational training in Germany, Social Networks 55: 74-85. doi: https://doi.org/10.1016/ j.socnet.2018.05.006.

Rousseeuw, P. J. (1987). Silhouettes: A graphical aid to the interpretation and validation of cluster analysis, Journal of Computational and Applied Mathematics 20: 53-65. doi: https://doi.org/10.1016/0377-0427(87)90125-7.

Schoon, I., \& Duckworth, K. (2010). Leaving School Early - and Making It! Evidence From Two British Birth Cohorts, European Psychologist 15(4): 283-92. doi: https://doi. org/10.1027/1016-9040/a000063.

Schoon, I., \& Lyons-Amos, M. (2016). Diverse pathways in becoming an adult: The role of structure, agency and context, Research in Social Stratification and Mobility 46: 11-20. doi: https://doi.org/10.1016/j.rssm.2016.02.008.

Skolinspektionen (2014). Kunskapsöversikt för studieavbrott i gymnasieskolan. [Knowledge overview on interruptions in upper secondary education].

Skolverket (2013). Beskrivande data 2012. Förskola, skola och vuxenutbildning. Rapport 383 [Descriptive data 2012. Pre-school, school, and adult education. Report 383]. Stockholm: Fritzes.

Statistics Sweden (2017a). Olika levnadsvillkor för barn med svensk och utländsk bakgrund [Different living conditions for children with Swedish and foreign background].

Statistics Sweden (2017b). Temarapport 2017: 4. Unga utanför? Så har det gått på arbetsmarknaden för 90-talister utan fullföljd gymnasie utbildning [Theme report 2017: 4. Young people left behind? The situation on the labour market for those born in the 1990s without completed upper secondary education], Örebro: SCB.

Statistics Sweden (2018). Hur gick det för eleverna som var obehöriga till gymnasieskolan? [What happened to the students lacking qualifications to upper secondary school?].

Strømme, T. B. (2020). Educational aspirations and decisions in Barcelona, Spain and Bergen, Norway: the significance of class and class fractions, Journal of Youth Studies: 1-22. doi: https://doi.org/10.1080/13676261.2020.1741526.

Struffolino, E., \& Borgna, C. (2020). Who is really 'left behind'? Half a century of gender differences in the school-to-work transitions of low-educated youth, Journal of Youth Studies: 1-24. doi: https://doi.org/10.1080/13676261.2020.1713308.

Thaning, M., \& Hällsten, M. (2020). The End of Dominance? Evaluating Measures of Socio-Economic Background in Stratification Research, European Sociological Review 36(4): 533-47. doi: https://doi.org/10.1093/esr/jcaa009. 
Universitetskanslersämbetet (2015). Etableringen på arbetsmarknaden för högskoleutbildade 2013: Examinerade läsåren 2011/12, 2009/10 och 2007/08. Rapport 2015: 26 [Establishment in the labour market for people with university education in 2013: Exams from academic years 2011/12, 2009/10, and 2007/2008. Report 2015: 26], Stockholm: Universitetskanslersämbetet.

Van Caudenberg, R., Van Praag, L., Nouwen, W., Clycq, N., \& Timmerman, C. (2017). A Longitudinal Study of Educational Trajectories of Youth at Risk of Early School Leaving. Antwerp: Centre for Migration and Intercultural Studies.

Van Praag, L., \& Clycq, N. (2019). Going to work without educational qualifications: schoolto-work transitions of early school leavers in Belgium, Journal of Youth Studies 23(4): 465-80. doi: https://doi.org/10.1080/13676261.2019.1620926.

Vogt, K. C., Lorentzen, T., \& Hansen, H.-T. (2020). Are low-skilled young people increasingly useless, and are men the losers among them?, Journal of Education and Work 33(5-6): 392-409. doi: https://doi.org/10.1080/13639080.2020.1820965.

Zschirnt, E., \& Ruedin, D. (2016). Ethnic discrimination in hiring decisions: a meta-analysis of correspondence tests 1990-2015, Journal of Ethnic and Migration Studies 42(7): 1115-34. doi: https://doi.org/10.1080/1369183x.2015.1133279.

\section{Note}

${ }^{1}$ The immigrant background categories were based on registry data identifying 73 different countries or country groups, and were defined as follows:

North-West: Australia and Oceania, Austria, Belgium, Canada, Denmark, Finland, France, Germany, Greece, Iceland, Ireland, Italy, Japan, Luxemburg, Netherlands, Norway, Portugal, Spain, Switzerland, UK and USA. Central and Eastern Europe: Bosnia-Herzegovina, Bulgaria, Croatia, Czech Republic, Estonia, Hungary, Latvia, Lithuania, Macedonia, Poland, Romania, Russia and Former Soviet Union, Slovakia, Slovenia, Yugoslavia, and Other Europe. Latin America: Argentina, Bolivia, Brazil, the Caribbean, Central America, Chile, Colombia, Mexico, Peru, Other South America. MENA: Algeria, Egypt, Iran, Iraq, Lebanon, Morocco, Syria, Tunisia, Turkey and Other Middle East. Rest of Asia: Afghanistan, Bangladesh, Cambodia, China, India, Pakistan, Phillipines, South Korea, Sri Lanka, Thailand, Vietnam, and Other Asia. Sub-Saharan Africa: Eritrea, Ethiopia, Gambia, Somalia, Uganda and Other Africa. 


\section{Appendix}

Figure AI Sequence percentage plots for the four principal clusters of school-to-work trajectories found among Swedish early school leavers born in 1984 and 1985, using alternative threshold for being established in the labor market ( $80 \%$ of median earnings).

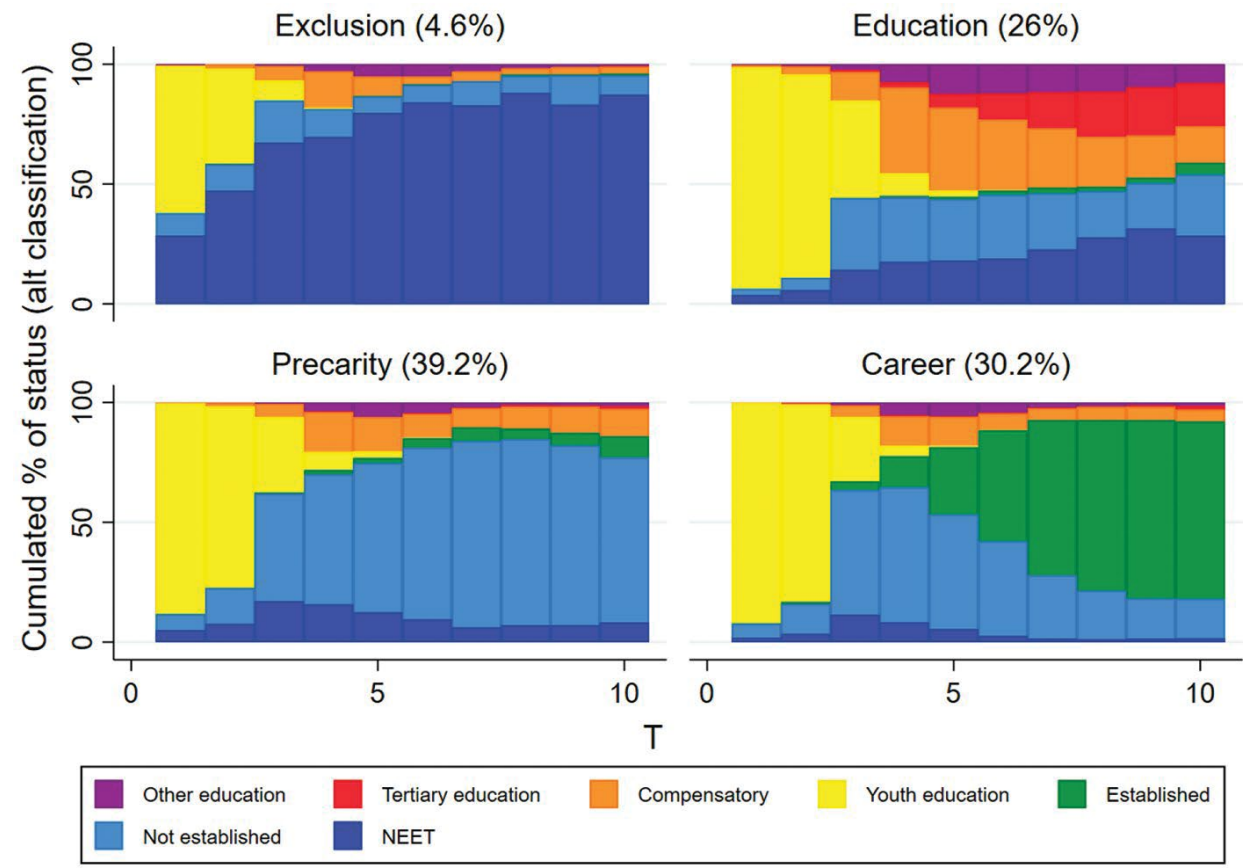

Cumulative percentage of individuals in each state ( $y$-axis) and years after compulsory school ( $x$-axis). Weighted percentage share of early school leavers in each cluster in parentheses after cluster name. 
Table AI Predictors of school-to-work trajectory for Swedish young adults who left school without completing upper secondary education, using alternative threshold for being established in the labor market ( $80 \%$ of median earnings)

\begin{tabular}{|c|c|c|c|c|}
\hline & Exclusion & Education & Precarity & Career \\
\hline \multicolumn{5}{|c|}{ Parents' region of birth (ref: Sweden) } \\
\hline \multirow[t]{2}{*}{ North-West } & 0.01 & 0.04 & 0.02 & $-0.07^{* *}$ \\
\hline & $(0.01)$ & $(0.02)$ & $(0.03)$ & $(0.02)$ \\
\hline \multirow[t]{2}{*}{ Central/East Europe } & 0.01 & $0.08^{* *}$ & -0.03 & $-0.06^{*}$ \\
\hline & $(0.01)$ & $(0.03)$ & $(0.02)$ & $(0.02)$ \\
\hline \multirow[t]{2}{*}{ Latin America } & -0.01 & $0.14^{* * *}$ & 0.02 & $-0.15^{* * * *}$ \\
\hline & $(0.01)$ & $(0.02)$ & $(0.03)$ & $(0.02)$ \\
\hline \multirow[t]{2}{*}{ MENA } & -0.00 & $0.2 I^{* * * *}$ & $-0.07^{*}$ & $-0.14^{* * *}$ \\
\hline & $(0.01)$ & $(0.03)$ & $(0.03)$ & $(0.02)$ \\
\hline \multirow[t]{2}{*}{ Rest of Asia } & -0.01 & $0.09^{* *}$ & 0.04 & $-0.1 I^{* * * *}$ \\
\hline & $(0.01)$ & $(0.03)$ & $(0.03)$ & $(0.02)$ \\
\hline \multirow[t]{2}{*}{ Sub-Saharan Africa } & $0.04^{*}$ & $0.31^{* * *}$ & $-0.1 I^{* * *}$ & $-0.24^{* * *}$ \\
\hline & $(0.02)$ & $(0.03)$ & $(0.03)$ & $(0.02)$ \\
\hline \multirow[t]{2}{*}{ Parents' income, I 00k SEK } & -0.00 & -0.01 & -0.01 & 0.02 \\
\hline & $(0.00)$ & $(0.01)$ & $(0.02)$ & $(0.01)$ \\
\hline \multirow[t]{2}{*}{ Parents' years of schooling } & -0.00 & $0.03^{* * *}$ & $-0.0 I^{*}$ & $-0.0 I^{*}$ \\
\hline & $(0.00)$ & $(0.00)$ & $(0.01)$ & $(0.01)$ \\
\hline \multirow[t]{2}{*}{ Woman } & $0.01^{*}$ & $0.10^{* * *}$ & $0.19^{* * *}$ & $-0.3 I^{* * *}$ \\
\hline & $(0.01)$ & $(0.02)$ & $(0.02)$ & $(0.02)$ \\
\hline Observations & 6404 & 6404 & 6404 & 6404 \\
\hline
\end{tabular}

Average marginal effects from weighted multinomial logistic regression. Models control for grades from compulsory school and birth year. Robust standard errors, clustered by schools. $\mathrm{N}=6404 .{ }^{*} \mathrm{p}<0.05$, ${ }^{*} \mathrm{p} p<0.01$, **** $\mathrm{p}<0.00$ I. 